\title{
O SAGRADO E A TEATRALIZAÇÃO DO MUNDO: ESPAÇOS DE SALVAÇÃO E PURGAC̄̃̃O NOS RELATOS DAS BEATAS DO PADRE CÍCERO*
}

\section{Edianne dos Santos Nobre*}

Universidade Federal do Rio de Janeiro

\section{Resumo}

Este trabalho se propõe a analisar a construção do espaço de Juazeiro (sul do Ceará) como um lugar de purgação e salvação nas imagens presentes em um conjunto de narrativas femininas no final do século XIX.

\section{Palavras-chave}

Juazeiro - beatas - narrativas femininas.

* Este artigo se baseia na minha dissertação de mestrado intitulada $O$ teatro de Deus: a construção do espaço sagrado em Juazeiro a partir de narrativas femininas, sob orientação do prof. dr. Durval Muniz de Albuquerque Junior, Universidade Federal do Rio Grande do Norte, 2010, e que contou com o financiamento da Coordenação de Aperfeiçoamento de Pessoal de Nível Superior (Capes). Essa dissertação foi publicada em 2011 (sem esse capítulo) com o título $O$ teatro de Deus: as beatas do padre Cícero e o espaço sagrado de Juazeiro. Fortaleza: UFC/IMEPH, 2011. Agradeço a leitura atenta e cuidadosa da profa. Jacqueline Hermann sobre esta última versão.

** Doutoranda em História pelo Programa de Pós-Graduação em História Social da Universidade Federal do Rio de Janeiro e bolsista da Capes. 


\section{THE SACRED AND}

THE DRAMATIZATION

OF THE WORLD:

SPACES OF SALVATION

AND PURGATION

IN THE REPORTS OF

RELIGIOUS WOMEN

RELATED WITH PADRE

CICERO

Contact

Universidade Federal do Rio de Janeiro Largo de São Francisco, 1 - sala 205 20051-070 - Rio de Janeiro - Rio de Janeiro E-mail: e.snobre@gmail.com

\section{Edianne dos Santos Nobre}

Universidade Federal do Rio de Janeiro

\section{Abstract \\ The objective of this work is to analyze the construction of the space of Juazeiro (south of Ceará) as a place of purgation and salvation from the images present in a group of feminine narratives belonging to the end of the 19th century.}

\section{Keywords}

Juazeiro - religious women - feminine narratives. 
REVISTA DE HISTÓRIA

SÃO PAULO, N $N^{\circ} 169$, p. 381-409,

JULHO / DEZEMBRO 2013
Edianne dos Santos Nobre

0 sagrado e a teatralização do mundo: espaços de salvação e purgaç̃ão nos relatos das beatas do padre Cícero

Na madrugada de 6 de março de 1889, primeira sexta-feira da quaresma daquele ano, na capela de Nossa Senhora das Dores em Juazeiro, ${ }^{1}$ após uma exaustiva noite de orações e penitências oferecidas ao Santíssimo Sacramento, o padre Cícero Romão Batista ${ }^{2}$ decide encerrar a noite de vigílias ministrando a comunhão da Sagrada Eucaristia às pessoas que ali estavam. Ao receber a comunhão, a beata Maria Magdalena do Espírito Santo de Araújo foi tomada por uma "veemente dor, unida ao mesmo tempo a uma grande consolação da alma".

Em sua língua, a hóstia recém-consumida se transformou em sangue pela primeira vez e, a partir daquele momento, ela seria, segundo seus próprios depoimentos, a esposa fiel de Cristo com a missão de "converter os pecadores, santificar as almas e liberar as almas do purgatório". O sangue precioso que ali se derramara teria como objetivo fazer daquele lugar "uma porta do céu e um lugar de salvação para as almas". ${ }^{3}$ Segundo o padre Cícero, o fenômeno reproduziu-se durante todo o tempo quaresmal daquele ano e "principalmente às quartas e sextas-feiras de cada semana [...] o que se deu também uma vez, no sábado da Paixão no mencionado ano, depois do que passaram a ser diários até a Ascensão do Senhor".4

Maria de Araújo tinha 27 anos, morava com sua família e vivia de pequenas costuras, com as quais também ajudava no sustento da casa. A partir de março de 1889 e com a popularidade que o sangramento da hóstia ganhou, ela começou a ser visitada por curiosos e pelos que acreditavam que o sangue que vertia de suas comunhões era o sangue verdadeiro de Cristo. Ainda naquele ano, mudou-se para a casa do padre Cícero, onde já vivia a

\footnotetext{
${ }^{1}$ O povoado de Juazeiro está situado no vale (ou região) do Cariri (que tem esse nome por causa da presença de índios da etnia Kariri), no sul do Ceará, a 580 km de distância da capital Fortaleza. Ao longo do texto, faremos referência ao lugar como região do Cariri. A partir de sua emancipação política em 1911, o povoado passou a se chamar oficialmente Juazeiro do Norte. A capela de Juazeiro foi criada em 1827, pelo padre Pedro Ribeiro (1790? -1856). É a atual matriz de Juazeiro do Norte.

2 Cícero Romão Batista nasceu na cidade do Crato em 24 de março de 1844, filho de Joaquim Romão Batista e Joaquina Vicência Romana. Formou-se sacerdote no Seminário da Prainha em 30 de novembro de 1870 e chegou à povoação do Juazeiro em 1872, permanecendo lá até sua morte em 20 de julho de 1934.

3 Relato construído a partir dos depoimentos de Maria de Araújo (09/09/1981) e do padre Cícero Romão (17/07/1891). In: Cópia autêntica do processo instruído sobre os fatos do Juazeiro. Arquivo do Departamento Histórico Diocesano Padre Gomes, Crato-CE, p. 04-08. Doravante citaremos como Cópia autêntica....

${ }^{4}$ Exposição circunstanciada do padre Cícero R. Batista em 17/07/1891. In: Cópia autêntica..., op. cit., p. 04.
} 
REVISTA DE HISTÓRIA

SÃO PAULO, N 169 , p. 381-409,

JULHO / DEZEMBRO 2013
Edianne dos Santos Nobre

0 sagrado e a teatralização do mundo: espaços de salvação e purgação nos relatos das beatas do padre Cícero

beata Joanna Tertulina (1864-1944), conhecida como beata Mocinha, ${ }^{5}$ secretária e governanta do padre.

Como as outras mulheres presentes na capela naquela sexta-feira, Maria de Araújo era zeladora do Apostolado da Oração, uma associação leiga que nasceu na França em 1844 e foi aprovada pelo papa Pio IX em 1849, também conhecida como Associação do Sagrado Coração de Jesus. A primeira sessão do Apostolado da Oração na região do Cariri foi inaugurada na capela do Juazeiro em 1888. Naquele contexto, a organização das mulheres em associações femininas controladas pela Igreja foi fundamental para que se destituísse do laicato qualquer tipo de poder no campo religioso.

Apesar disso, as leigas que participavam dessa associação eram chamadas de beatas, ainda que não saibamos se essa era uma denominação comum a todas as mulheres do Apostolado na época ou se era um caso peculiar de Juazeiro. ${ }^{6}$ Elas eram vistas como mulheres que seguiam ou tentavam seguir um modelo de perfeição e virtude, o que denota a importância da atividade religiosa leiga na região e o que, segundo Leila Algranti, justificaria a notoriedade dessas mulheres entre a população. ${ }^{7}$

Em 1891, a Diocese cearense instaurou um processo episcopal que teria como finalidade investigar o caráter do fenômeno acontecido com Maria de Araújo no pequeno povoado de Juazeiro, cidade do Crato, sul do Ceará. A partir da investigação das condições nas quais se dava o sangramento da hóstia, a comissão de inquérito deveria dizer se o fenômeno era um milagre ou não. Nesse processo, encontramos, no entanto, não só a narrativa sobre a hóstia sangrenta, mas também relatos de outros fenômenos que ocorriam com Maria de Araújo e com outras oito beatas desde antes de 1889. No rol

\footnotetext{
5 A beata Mocinha nasceu em 27 de janeiro de 1864, na freguesia do Riacho do Sangue - atual Jaguaretama, norte do Ceará -, sendo filha de Francisco Antônio de Oliveira e Maria Teotônia de Oliveira. Ficou órfã em 1879 e foi morar na povoação de Juazeiro com uma senhora chamada d. Naninha. Em 1885, ela recebeu o manto de beata na mesma solenidade que conferiu o manto às beatas Maria de Araújo, Maria das Dores, Jahel Cabral e Maria da Soledade. Não sabemos quando ela foi morar na casa do padre Cícero, mas é certo que em 1889 já estava lá (Cf. Alencar; Meneses, s/d).

${ }^{6}$ É importante lembrar que, naquele momento, o termo beata ainda não possuía o caráter pejorativo que Renata Marinho Paz faz menção em seu livro, pelo menos não na região do Cariri. Cf. PAZ, Renata Marinho. As beatas do padre Cícero: Participação feminina leiga no movimento sociorreligioso de Juazeiro do Norte. Juazeiro do Norte: Editora Ipesc/Urca, 1998. A partir da leitura de parte das fontes documentais, percebemos que as beatas eram muito respeitadas pela população local e, mesmo, exemplos de moral e virtude.

7 ALGRANTI, Leila Mezan. Honradas e devotas: mulheres da colônia. Rio de Janeiro: José Olympio; Brasília: EdUnB, 1993.
} 
REVISTA DE HISTÓRIA

SÃO PAULO, N ${ }^{\circ} 169$, p. 381-409,

JULHO / DEZEMBRO 2013
Edianne dos Santos Nobre

0 sagrado e a teatralização do mundo: espaços de salvação e purgação nos relatos das beatas do padre Cícero

desses fenômenos extraordinários, temos relatos de sangramentos de crucifixos de metal maciço, êxtases, viagens espirituais ao Céu, Inferno e Purgatório, visões de santos, de Cristo e da Virgem Maria e revelações proféticas. ${ }^{8}$

Nas obras mais recentes sobre o tema (últimos 30 anos do século XX e primeira década do XXI), a visão da cidade como um espaço de fanatismo foi se transformando paulatinamente. Além da renovação das teorias do pensamento geográfico e das novas formas de percepção e concepção do espaço, essa transformação é decorrente também de influências pós-Concílio Vaticano II e da nova postura da Igreja católica diante das romarias, principalmente, após a década de $1970 .^{9}$

O antropólogo Salatiel Barbosa, em seu livro intitulado O Joaseiro celeste: tempo e paisagem na devoção ao padre Cícero, ${ }^{10}$ defende que Juazeiro foi construída e reconstruída em um fluxo constante onde o espaço é provisório, constantemente modificado e reificado pelos seus praticantes. Barbosa fez uma espécie de esquadrinhamento dos espaços de devoção mais visitados pelos romeiros e procurou neles as representações e significações míticas empreendidas por eles. O horto, a igreja matriz, o santo sepulcro, a capela inacabada, a ladeira, são comparadas aos espaços bíblicos, se transmutam nesses espaços. Juazeiro é, portanto, uma "Nova Jerusalém" porque seus andantes estão refazendo a caminhada de Jesus Cristo.

Para Régis Lopes Ramos, o mesmo se dá com “[...] a fundação da sacralidade de Juazeiro, com o fluxo de sangue e peregrinos, não é a colocação de um centro no espaço e sim a própria constituição do espaço por meio

\footnotetext{
${ }^{8}$ O primeiro inquérito "acerca dos fatos extraordinários ocorridos nesta povoação do Juazeiro" foi instaurado pelo bispo diocesano dom Joaquim José Vieira em 19 de julho de 1891, depois de ouvir o padre Cícero Romão Batista falar sobre as circunstâncias de produção dos fenômenos e sobre a conduta da beata Maria de Araújo. A comissão responsável por ele era composta pelos padres Clicério da Costa Lobo e Francisco Ferreira Antero. O inquérito foi encerrado em setembro de 1891 com a conclusão de que os fenômenos eram sobrenaturais e divinos, portanto, milagres. O bispo diocesano recusou esse primeiro inquérito e instaurou um segundo, em abril de 1892, cujo delegado episcopal era o padre Antonio Alexandrino de Alencar. Esse segundo inquérito considerou que os fenômenos das beatas eram embustes e que as beatas, embusteiras. Não entrarei aqui no âmbito dessa discussão que ensaiei na minha dissertação de mestrado já publicada. Ver: NOBRE, Edianne S. O teatro de Deus: a construção do espaço sagrado de Juazeiro a partir de narrativas femininas (Ceará, 1889-1898). Fortaleza, CE: IMEPH/UFC, 2011.

9 Sobre as romarias e a atuação eclesiástica nos movimentos pastorais em Juazeiro do Norte e Crato ver a Introdução e capítulos 3-6 de PAZ, Renata Marinho. Para onde sopra o vento: a Igreja Católica e as romarias de Juazeiro do Norte. Fortaleza: UFC/IMEPH, 2011.

${ }^{10}$ Ver BARBOSA, Francisco Salatiel de Alencar. O Joaseiro celeste: tempo e paisagem na devoção ao padre Cícero. São Paulo: Attar, 2007.
} 
REVISTA DE HISTÓRIA

SÃO PAULO, N 169 , p. 381-409,

JULHO / DEZEMBRO 2013
Edianne dos Santos Nobre

0 sagrado e a teatralização do mundo: espaços de salvação e purgação nos relatos das beatas do padre Cícero

das vivências que fazem o centro".11 Para Ramos assim como para Barbosa, o espaço é também fundado nas vivências e no imaginário dos devotos; "Juazeiro é uma construção histórica, que se compõe das experiências dos devotos [...] as vivências se concretizam no e pelo espaço [...]".12 Portanto, para esses dois autores, são as caminhadas e trajetórias dos romeiros que irão constituir um espaço sagrado.

Essa historiografia mais recente traz também de volta ao cenário de Juazeiro a atuação da beata Maria de Araújo. A simbologia do milagre eucarístico foi interpretada pela psicóloga Maria do Carmo Pagan Forti em Maria do Juazeiro: a beata do milagre. ${ }^{13}$ Forti busca interpretações para o evento na própria história de vida da beata Maria de Araújo, no entanto, não se detém em analisar os relatos e narrativas das outras mulheres. Apesar de fazer uma discussão sobre a condição da mulher e sobre as estratégias de repressão ao corpo feminino, a autora acaba reforçando, com suas argumentações, o papel coadjuvante de Maria de Araújo no cenário religioso de Juazeiro do Norte. Além disso, não aparecem as outras mulheres envolvidas no processo.

Já a antropóloga Renata Marinho Paz, no já citado As beatas do padre Cícero, busca, na criação das casas de caridade e na ação do padre José Maria Ibiapina, do qual falaremos mais adiante, a origem da atuação das beatas naquela região. ${ }^{14} \mathrm{O}$ estudo é importante porque colocou em cena as mulheres, além de trazer um elemento novo para a historiografia sobre o tema: uma de suas hipóteses é justamente que o esquecimento imposto sobre as beatas abriu espaço "para sua caracterização como embusteiras e fanáticas". ${ }^{15}$

A carência de estudos que mostrem a perspectiva dessas mulheres em relação aos eventos de que foram protagonistas é, no mínimo, um indício de que as medidas castradoras da Igreja Católica Apostólica Romana - representada pela Diocese cearense - foram eficientes, uma vez que o processo de obliteração inicia-se em sua contemporaneidade.

\footnotetext{
${ }^{11}$ RAMOS, Francisco Régis Lopes. O meio do mundo: territórios do sagrado em Juazeiro do padre Cícero. Tese de doutoramento, PUC-SP, São Paulo, 2000, p. 06 (Cedida pelo autor).

${ }^{12}$ Idem, p. 10-11.

${ }^{15}$ FORTI, Maria do Carmo Pagan. Maria do Juazeiro: A beata do milagre. São Paulo: Annablume, 1999.

${ }^{14}$ As casas de caridades, cujo lema era Ora et labora (Ora e trabalha), são instituições criadas pelo padre José Antônio Maria Ibiapina, em meados do século XIX, que estimulavam práticas devocionais inspiradas no modelo católico luso-brasileiro. Ver: HOORNAERT, Eduardo (org.). Crônicas das casas de caridade fundadas pelo padre Ibiapina. Fortaleza: Museu do Ceará/Secretaria de Cultura do Ceará, 2006.

${ }^{15}$ PAZ, Renata Marinho, op. cit., p. 84.
} 
REVISTA DE HISTÓRIA

SÃO PAULO, N $N^{\circ} 169$, p. 381-409,

JULHO / DEZEMBRO 2013
Edianne dos Santos Nobre

0 sagrado e a teatralização do mundo: espaços de salvação e purgação nos relatos das beatas do padre Cícero

Estes autores, embora contribuam bastante para os estudos das romarias e peregrinações religiosas no campo das Ciências Humanas, continuam, todavia, reforçando uma história oficial centralizada no padre Cícero. Esta postura indica que a memória e a narrativa histórica dos eventos de Juazeiro nunca foi uma memória/história das beatas.

Nossas inquietações acerca da narrativa histórica, literária ou memorialista sobre os eventos de Juazeiro partem, portanto, da constatação de uma obliteração desse grupo de mulheres (leigas e, em sua maioria, pobres e analfabetas) e da centralização na pessoa do padre Cícero Romão Batista que, apesar de ser tido como um refratário às decisões diocesanas, representa o mundo eclesiástico, essencialmente masculino. É a partir da constatação dessa "falta" que pretendemos analisar os depoimentos dessas mulheres, observando as representações espaciais construídas sobre o povoado de Juazeiro, na medida em que o processo foi sendo executado. Que imagens elas usaram para significar aquele espaço como um lugar de salvação? Quais os elementos presentes nas narrativas que nos oferecem a possibilidade de pensar aquele espaço como um Purgatório na terra?

\section{Casa dos milagres: as imagens do sagrado na capela de Nossa Senhora das Dores}

No Ceará do século XIX, a criação do bispado em 1860 e a nomeação de d. Luís Antônio dos Santos (1817-1891) para ocupar o cargo de bispo foi, segundo o jornal $O$ Cearense, providencial no sentido de impor ordem ao desregramento moral e social que atingia os leigos e a própria Igreja. O primeiro bispo cearense empreendeu uma severa perseguição às comunidades leigas e aos seus dirigentes ou pais espirituais. Neste sentido, destaca-se a oposição que a Diocese fez à atividade missionária do padre José Antônio de Maria Ibiapina (1806-1883). ${ }^{16}$

\footnotetext{
${ }^{16}$ Entre 1860 e 1876, Ibiapina percorreu os estados do Ceará, Paraíba, Piauí, Pernambuco e Rio Grande do Norte, construindo poços e açudes para o abastecimento de água nas regiões mais carentes e mais atingidas pelas secas constantes. Ibiapina organizou ainda a construção de igrejas, cemitérios e casas de caridade nos lugares onde as ações governamentais falhavam. É sabido que, a despeito de sua formação oratoriana, sua pregação era marcada pelas mesmas características da pregação penitencial da época, mas ele também estimulava o "combate à miséria e aos pecados [através] do redirecionamento das energias do povo para o trabalho em prol de melhorias para a coletividade", como ressalta Renata Marinho Paz, op. cit., p. 46.
} 
REVISTA DE HISTÓRIA

SÃO PAULO, N 169 , p. 381-409,

JULHO / DEZEMBRO 2013
Edianne dos Santos Nobre

0 sagrado e a teatralização do mundo: espaços de salvação e purgação nos relatos das beatas do padre Cícero

Dentre as obras sociais do padre Ibiapina, destacamos a construção das casas de caridade que passaram a congregar mulheres que se dispunham a uma vida religiosa, mas não tinham meios de entrar nas ordens religiosas eclesiásticas. ${ }^{17}$ Essas casas eram, em sua constituição, beatérios que imitavam o modelo europeu dos recolhimentos femininos de mulheres leigas, muito comuns na Europa e que migraram para o Brasil colonial. ${ }^{18}$

Embora essas casas de caridade não tivessem aprovação canônica, as mulheres que nelas entravam respondiam a um dos modelos de virtude valorizados pela Igreja. Essa relação era representada através de práticas como meditações, cantorias, ladainhas, festas votivas e romarias, consideradas supersticiosas na concepção da Igreja de fins do século XIX que lutava por purificar a religião praticada pelo povo. ${ }^{19}$

Em 1888, o sucessor de d. Luís, o bispo dom Joaquim José Vieira (18361917), promoveu o primeiro Sínodo Diocesano cearense (também, o primeiro brasileiro) que incorporava as decisões do Concílio Vaticano I (1869-1870) e dava forma à romanização do clero. Esse sínodo expressava as principais preocupações da Igreja católica e, em particular, da Diocese cearense, no sentido

\footnotetext{
${ }^{17}$ O padre Ibiapina ergueu ao todo no Ceará "vinte casas de caridade, dez igrejas, dez açudes, nove cemitérios, quatro hospitais, quatro capelas, uma casa paroquial, uma cacimba pública e um gabinete de leitura". Cf. PAZ, Renata Marinho, op. cit., 2005, p. 47, nota 33. Na região do Cariri, foram construídas quatro casas de caridade nas cidades de Missão Velha, Barbalha, Milagres e Crato entre os anos de 1864 a 1869. A Casa de Caridade do Crato foi erguida em 7 de março de 1869.

${ }^{18}$ Apesar de não pertencerem a nenhuma ordem oficial, as beatas das casas de caridade do Cariri faziam votos de obediência, pobreza e castidade e vestiam hábitos religiosos como os das freiras. Além disso, a casa recebia órfãos abandonados, crianças enjeitadas (deixadas na roda dos enjeitados) e "pensionistas" (mulheres abandonadas pelos maridos ou pelos parentes próximos). A organização da casa era feita mediante a disposição das habilidades de cada mulher. A superiora geral cuidava da administração das tarefas e do dinheiro da casa sendo subordinada ao sacerdote que apadrinhava a casa. Outras funções que as mulheres podiam exercer eram de mestras (professoras), enfermeiras e zeladoras: porteira, roupeira (lavava roupa), cozinheira. Cada casa contava ainda com um beato que arrecadava esmolas e outros bens para a casa, embora este não pudesse entrar nela. Cf. IBIAPINA, José Antônio Maria. Regulamento interno para as casas de caridade do Crato de 09/04/1872. Departamento Histórico Diocesano Padre Gomes.

${ }^{19}$ A "romanização", como ficou conhecida a política ultramontana no Brasil foi uma tendência eclesiástica de defender a Igreja e as prerrogativas do bispo de Roma, como: o primado do papa, a consolidação de uma política de centralização romana, tornando Roma um modelo a ser seguido. Fazendo referência aos que aceitavam aderir ao primado de Roma, mesmo estando "além dos montes", o ultramontanismo se apresenta, pois, como uma política eclesiástica antiliberal que não só reforça a reforma tridentina como privilegia a clericalização e a uniformização. Ver: BEOZZO, José Oscar et al. História da Igreja no Brasil: Ensaio de interpretação a partir do povo. Segunda época - século XIX. $4^{\mathrm{a}}$ edição. Petrópolis, RJ: Vozes, 2008; VAUCHEZ, André. Les laïcs au Moyen-Âge entre ecclésiologie et histoire. Études 2005/1, Toe 402, p. 55-67.
} 
REVISTA DE HISTÓRIA

SÃO PAULO, N ${ }^{\circ} 169$, p. 381-409,

JULHO / DEZEMBRO 2013
Edianne dos Santos Nobre

0 sagrado e a teatralização do mundo: espaç̦os de salvação e purgaç̃ão nos relatos das beatas do padre Cícero

de conter algumas "manifestações exacerbadas" da religião, expressas principalmente na forma como os ritos eram conduzidos pelo laicato em geral. ${ }^{20}$

Também nesse sentido, a fundação do Apostolado da Oração em 1888, no povoado de Juazeiro, sob a direção espiritual do padre Cícero Romão Batista, se apresentou como uma estratégia de congregar as mulheres leigas religiosas fazendo com que elas seguissem uma rotina aprovada de acordo com os moldes reformistas. À semelhança do padre Ibiapina, o padre Cícero (que havia voltado para a região no fim de 1871, depois de sua ordenação como sacerdote) passou a recrutar as moças solteiras do povoado que quisessem seguir vida religiosa, mas desta vez elas estariam organizadas dentro de uma associação aprovada pela Igreja. ${ }^{21}$

Com a Proclamação da República no Brasil, a Igreja católica brasileira enfrentou também um embate que colocava em xeque sua postura diante do Estado, pois, por um lado, cessava o regime do padroado régio que até então mantinha os sacerdotes como "assalariados", além de dar o direito à Coroa de criar dioceses e indicar os bispos. Por outro lado, a laicização do Estado destituía da Igreja a exclusividade sobre alguns "direitos" dos católicos e instituiu, dentre outras mudanças, a laicização do matrimônio e dos cemitérios. ${ }^{22}$

Não obstante os conflitos entre a Igreja e o Estado, em 1890, foi divulgado o texto resultante da Pastoral Coletiva do Episcopado Brasileiro, no qual a Igreja jurava fidelidade ao novo regime. Nesse contexto da reforma eclesial, a organização das mulheres em associações femininas controladas pela Igreja foi fundamental para que se destituísse do laicato qualquer tipo de poder no campo religioso. A ação religiosa foi centrada nos sacramentos e os leigos foram organizados em associações de piedade dirigidas por sacerdotes.

No caso do Cariri, a atuação das religiosas leigas foi essencial nas transformações que ocorreram no povoado a partir de 1889, quando a hóstia

\footnotetext{
${ }^{20}$ Constituições sinodais de 1888. Arquivo da Cúria Diocesana - DHDPG.

${ }^{21}$ DELLA CAVA, Ralph. Milagre em Joaseiro. São Paulo: Paz e Terra, 1976.

${ }^{22}$ Em setembro de 1889, uma circular enviada pelo bispo d. Joaquim às paróquias da Diocese cearense expressava o desagrado do papa Leão XIII com a laicização do casamento: “Querendo Sua Santidade facilitar todos os meios de santificação e salvação das almas, e tendo em consideração o desgraçado estado a que se reduzem alguns infelizes que se deixam ficar em concubinato legal, pela união ilegítima sancionada pela lei do casamento civil, sem intervenção da Santa Igreja, e mesmo de outros que vivem em simples concubinato, expondo-se a morrer no triste estado de pecado [...] [seguem as prescrições]". Carta circular de dom Joaquim Vieira ao padre Cícero R. Batista em 04/09/1889. In: CASIMIRO, Renato. Documentário do Joaseiro. Arquivo da Cúria do Crato - DHDPG. Ressalte-se que a carta original foi emitida pela Secretaria da Sagrada Congregação do Santo Ofício em 29/02/1888.
} 
REVISTA DE HISTÓRIA

SÃO PAULO, N 169 , p. 381-409,

JULHO / DEZEMBRO 2013
Edianne dos Santos Nobre

0 sagrado e a teatralização do mundo: espaços de salvação e purgação nos relatos das beatas do padre Cícero

consagrada sangrou pela primeira vez na boca da beata Maria de Araújo na capela de Nossa Senhora das Dores. Muitos peregrinos passaram a visitar o povoado para prestar culto ao sangue precioso que jorrava da hóstia e começaram a fixar residência ali, daí o aumento da população, o desenvolvimento do comércio e a criação de ruas e escolas para atender às demandas da população adventícia.

Nesse espaço, destaca-se a então capela de Nossa Senhora das Dores, pois era lá o espaço de sociabilidade por excelência das beatas e devotos que acreditavam que o sangue ali derramado era o sangue de Cristo, embora seja forçoso notar que, nos depoimentos, por vezes os espaços da capela e do povoado se confundem, o que torna difícil distinguir a qual dos dois lugares as beatas fazem referência. Um espaço se torna extensão do outro, por isso falamos aqui de um espaço sagrado - Juazeiro - e de seus lugares de devoção: igreja, horto etc. Este espaço sagrado é ainda, por excelência, o espaço do espetáculo da aparição de anjos que entoam cânticos de louvor ao sangue precioso, juntamente com Jesus e Maria, como conta Maria de Araújo:

Além das revelações já expostas, declarou mais ter, assim antes da transformação das hóstias em sangue como, depois do fato, visto coros de Anjos, precedidos de Jesus e Maria entrando processionalmente na Igreja do Juazeiro com tochas acesas e entoando cânticos, todos em direção ao altar do Santíssimo para ali adorá-lo. ${ }^{23}$

Como explica Jean Delumeau, a cidade celeste era geralmente percebida pelos visionários sob a forma de uma igreja. Era ela mesma, “a figura da assembleia universal dos fiéis: a 'Igreja' com I maiúsculo, ainda 'militante' na terra, mas chamada a tornar-se um dia a Igreja 'triunfante' e eterna". ${ }^{24} \mathrm{~A}$ igreja de Juazeiro será imaginada nesse momento como um espaço onde o maravilhoso passou a se manifestar constantemente. Seu interior será palco de visões, revelações divinas e, principalmente, o lugar da adoração do sangue precioso de Cristo.

O espaço se converte, ainda, em um espaço da esperança de uma eterna felicidade no além, embora o caminho que se percorra até o Paraíso seja perpassado pela aura que alude ao sofrimento de Cristo. É um caminho de pedras e espinhos, mas que traz em si a promessa do gozo eterno. Nas visões, Cristo aparece sempre a derramar seu sangue e pede às suas "esposas" que, através

\footnotetext{
${ }^{23}$ Aditamento ao auto de perguntas feitas a Maria de Araújo, de 11/09/1891. In: Cópia autêntica, op. cit., p. 15.

${ }^{24}$ DELUMEAU, Jean. O que sobrou do Paraíso? São Paulo: Companhia das Letras, 2003, p. 110.
} 
REVISTA DE HISTÓRIA

SÃO PAULO, N $N^{\circ} 169$, p. 381-409,

JULHO / DEZEMBRO 2013
Edianne dos Santos Nobre

0 sagrado e a teatralização do mundo: espaç̦os de salvação e purgaç̃ão nos relatos das beatas do padre Cícero

do sofrimento, se unam a ele na tarefa de conversão das almas, a fim de fazer daquele lugar sua morada na terra, seu "outro céu", onde seriam vertidas "abundantes graças" para os que ali chegassem e se arrependessem dos seus pecados.

A igreja constitui uma imago mundi, uma imagem do mundo construída a partir do modelo geral do grande cosmos. Ambas se situam simbolicamente no centro do mundo, pois cada habitação traz em si a marca do habitante, é um "verdadeiro cosmos [...] a casa abriga o devaneio, a casa protege o sonhador". ${ }^{25}$ Também a Igreja enquanto imago mundi é para as beatas seu cosmos, um lugar de proteção contra o mal, é também sua casa e, posto que esteja localizada em um espaço sagrado, é a própria "imitação da Jerusalém celeste" e constitui uma "abertura para o alto" que assegura comunicação com o mundo divino. Segundo Mircea Eliade, toda igreja ou templo é, por sua estrutura, uma imitação do modelo da Jerusalém celeste, pois foi Jeová que revelou a Moisés e a seus eleitos os modelos do tabernáculo, dos utensílios sagrados e do Templo, desde a eternidade, para que fossem reproduzidos sobre a Terra. ${ }^{26}$

Neste lugar de devoção, as fronteiras entre a ortodoxia e a heterodoxia se diluem, no sentido em que estas mulheres se sentem autorizadas por Deus a proclamar "novos" cultos e práticas dentro do espaço de controle da ortodoxia - pois, embora tenha seu espaço ressignificado pelas experiências e vivências que ali se desenvolvem, a igreja (física) pertence primordialmente à Igreja oficial e está dentro da jurisdição da Diocese.

Também a mistura de elementos de ordem material e sobrenatural nas visões é significante dessa diluição das fronteiras, no que diz respeito à própria organização de mundo das beatas. A igreja de Nossa Senhora das Dores se torna um espaço de devoção que é continuamente ratificado nas visões que as beatas tinham com a igreja ou na igreja. O leitmotiv mais recorrente nessas visões é a imagem do derramamento ou do transbordamento:

Maria das Dores do Coração de Jesus, natural da freguesia de Missão Velha deste bispado e ora aqui residente, costureira, idade de quinze anos, solteira, testemunha jurada dos Santos Evangelhos [...] disse que uma vez viu a âmbula cheia de sangue a transbordar e derramar-se por todo o altar, aparecendo então Nosso Senhor todo ensanguentado, o qual nessa

\footnotetext{
${ }^{25}$ BACHELARD, Gaston. A poética do espaço. São Paulo: Nova Cultural, 1988, p. 199; 201.

${ }^{26}$ ELIADE, Mircea. O sagrado e o profano: a essência das religiões. São Paulo: Martins Fontes, 2001, p. 56-59.
} 
REVISTA DE HISTÓRIA

SÃO PAULO, N 169 , p. 381-409,

JULHO / DEZEMBRO 2013
Edianne dos Santos Nobre

0 sagrado e a teatralização do mundo: espaços de salvação e purgação nos relatos das beatas do padre Cícero

mesma ocasião deu a comunhão a Beata Maria de Araújo sob a espécie de pão tirando para esse fim uma partícula da mesma âmbula. ${ }^{27}$

O transbordamento do sangue na âmbula nos guia por sua vez ao transbordamento dos sentidos presentes nessa visão. No Novo Testamento, o sangue de Cristo alude ao caráter sacrificial da morte de Jesus: "e reconciliar por ele e para ele todos os seres, os da terra e os dos céus, realizando a paz pelo sangue da sua cruz" $(\mathrm{Cl} 1,20) .{ }^{28}$ É também através do sangue que seremos reconciliados por Deus (Ef 1.7; 2.13), isto é, no universo cristão é somente através do sacrifício (em que se baseia a penitência no catolicismo tradicional) e da expiação dos pecados (já predita no Antigo Testamento em Lv 6.30 e Ez 45.20) que é possível obter o perdão de Deus. A noção de sacrifício pode então ser entendida como "dom e abandono [...] compartilhamento de uma paixão que se traduz em comunhão experienciada através de gestos que levam aos excessos, ao aniquilamento". ${ }^{29}$ Não obstante, a missa católica também é chamada de sacrifício, pois a cena central e esperada do espetáculo é a comunhão eucarística, isto é, a divisão entre os fiéis da hóstia consagrada que "sob espécie de pão" representa o corpo de Cristo:

El mismo Dios, pues, y Señor nuestro, aunque se había de ofrecer a sí mismo a Dios Padre, una vez, por medio de la muerte en el ara de la cruz, para obrar desde ella la redención eterna; con todo, como su sacerdocio no había de acabarse con su muerte; para dejar en la última cena de la noche misma en que era entregado, a su amada esposa la Iglesia un sacrificio visible, según requiere la condición de los hombres [... $y$ permaneciese su memoria hasta el fin del mundo, y se aplicase su saludable virtud a la remisión de los pecados que cotidianamente cometemos. ${ }^{30}$

\footnotetext{
${ }^{27}$ Depoimento de Maria das Dores do Coração de Jesus de 18.09.1891. In: Cópia autêntica..., op. cit., p. 29. Grifo nosso.

${ }^{28}$ As referências bíblicas estão de acordo com a Bíblia de Jerusalém. São Paulo: Editora Paulus, 2012.

${ }^{29}$ SOUZA, Ana Guiomar Rêgo. Paixões em cena: a Semana Santa na cidade de Goiás (século XIX). Tese de doutoramento, Universidade de Brasília, Brasília-DF, 2007, p. 42.

${ }^{30}$ Tradução da autora: "O mesmo Deus, pois, e Senhor Nosso, ainda que se havia de oferecer a si mesmo a Deus Pai, uma vez que, através da morte sobre o altar da cruz, para obrar desde ela a redenção eterna; contudo, como seu sacerdócio não haveria de acabar-se com sua morte; para deixar na última ceia da mesma noite em que era entregue, a sua amada esposa, a Igreja, um sacrifício visível, segundo requer a condição dos homens [...] e permanecesse na memória até o fim do mundo, e se aplicasse sua saudável virtude à remissão dos pecados que cotidianamente cometemos". In: Documentos do Concílio de Trento, sessão XXII, cap. I "De la institución del sacrosanto sacrificio de la Misa". Disponível em Biblioteca electrónica cristiana - http://multimedios.org/docs/d000436/.
} 
REVISTA DE HISTÓRIA

SÃO PAULO, N $N^{\circ} 169$, p. 381-409,

JULHO / DEZEMBRO 2013
Edianne dos Santos Nobre

0 sagrado e a teatralização do mundo: espaços de salvação e purgaç̃ão nos relatos das beatas do padre Cícero

Segundo as prescrições do Concílio de Trento, a missa, tomada como sacrifício, serviria para relembrar a morte de Cristo na cruz que é a imagem central da Paixão. Na cultura barroca, a cruz é evocadora da própria memória da morte sacrificial do cordeiro e do drama de Maria, por isso, seguindo as prescrições de Trento, o texto das Constituições Primeiras do Arcebispado da Bahia manda que "nas Igrejas se ponham as Imagens de Cristo Nosso Senhor, de sua Sagrada Cruz, da Virgem Maria Nossa Senhora, e dos outros santos" e acrescenta que "sempre as Imagens de Cristo Nosso Senhor devem preceder a todas, e estar no melhor lugar; e logo as da Virgem Nossa Senhora". ${ }^{31}$

Na iconografia do catolicismo barroco, a cruz é também o elemento que unifica o culto da Paixão ao arcanjo Miguel que, como falamos, foi amplamente associado ao anjo Custódio do reino de Portugal. Para as beatas, o sangue que se derrama continuamente faz de Juazeiro um espaço onde aqueles que têm sede podem recorrer:

Jahel Wanderley Cabral, natural desta povoação do Juazeiro, deste bispado, idade de trinta e um anos, solteira, testemunha jurada dos Santos Evangelhos [...] Em dias do mês de julho de 1890, estando eu orando na Capela do Juazeiro, às oito horas da manhã, [...] eis que vi o mundo a sofrer uma grande tempestade, depois da qual tive de ver pássaros de todas as qualidades e de todas as cores, bebendo sangue contido em uma grande caixa; então um deles olhou para mim, e com o bico tinto de sangue me disse: estes pássaros são almas de toda qualidade, as quais virão de todas as partes e lugares a beber sua salvação no sangue de Nosso Senhor derramado aqui neste lugar. Esta visão foi seguida de outras. ${ }^{32}$

A visão é ambígua quanto à localização da "caixa". A expressão "aqui neste lugar" tanto pode ser a igreja onde acontece o milagre eucarístico com Maria de Araújo, como pode ser o próprio Juazeiro. Também pode ser uma referência à caixa de vidro que guardava os panos manchados com o sangue que brotava das "hóstias milagrosas" ou dos crucifixos sangrentos. Outra imagem próxima é citada pela beata Jahel no aditamento que fez ao seu depoimento no primeiro inquérito que "Desde a vez primeira que apareceu aqui sangue nas hóstias consagradas me foi revelado divinamente que aqui (na Capela do S. S.) seria como outra piscina, onde muitos se lavariam assim na alma, como no corpo". ${ }^{33}$ Como várias visões vêm claramente advertir sobre a segunda vinda de Cristo, podemos aferir que a visão da beata Jahel vem ainda

\footnotetext{
${ }^{31}$ Constituições Primeiras do Arcebispado da Bahia, sessão XX-696/699.

${ }^{32}$ Aditamento de Jahel Wanderley Cabral de 05/10/1891 In: Cópia autêntica..., op. cit., p. 51. Grifo nosso.

${ }^{3}$ Idem, p. 53.
} 
REVISTA DE HISTÓRIA

SÃO PAULO, N 169 , p. 381-409,

JULHO / DEZEMBRO 2013
Edianne dos Santos Nobre

0 sagrado e a teatralização do mundo: espaços de salvação e purgação nos relatos das beatas do padre Cícero

anunciar a transformação do espaço em um lugar de peregrinação, onde os pássaros são as almas (peregrinos) que viriam ver e beber do sangue precioso, arrependendo-se de seus pecados e convertendo-se à religião de Cristo.

Finalmente, o sangue precisa ser derramado, pois, segundo o próprio Cristo, na voz da beata Jahel Cabral, do mesmo modo que serve para a salvação, serve também como punição: "o sangue que derramei e [que] hei de derramar servirá de castigo para os que não acreditarem na minha onipotência". ${ }^{34}$ A caixa repleta de sangue é a imagem que representa o espaço sacralizado, é o lugar aonde as "almas de toda qualidade" recorrem, pois, ali é o centro do mundo, um espaço que vive "em comunicação com o mundo divino". ${ }^{35}$

Outra referência que a "caixa de sangue" evoca é a imagem do lagar místico. A partir da difusão ao culto eucarístico e às chagas de Cristo, é possível, já no século XIII, identificar, na iconografia religiosa que fazia representações da paixão de Cristo, a imagem do lagar místico como um tanque que abrigava o sangue que escorria das chagas de Jesus. O próprio tema do sangue que escorre é recorrente nas imagens do lagar:

[No] final do século $\mathrm{XV}$, a imagem do lagar místico era tratada de maneira realista e dolorista, pois era preciso atrair a atenção sobre os sofrimentos do Redentor, para avivar a compaixão dos fiéis. Assim como o cacho de uvas era esmagado no lagar, Cristo estava sujeito às opressões da cruz e aos sofrimentos da paixão. Chegou-se até mesmo a representar a imagem surpreendente do Pai ativando ele mesma a prensa do lagar que fazia jorrar o sangue do corpo de Cristo. ${ }^{36}$

A caixa sangrenta descrita por Jahel serve de apara ao sangue de Cristo, como um lagar serve de apara ao suco da uva que será transformado em vinho. Não sabemos se a imagem do lagar era uma imagem conhecida dessas mulheres, mas sabemos que certamente era conhecida dos sacerdotes, eles mesmos conhecedores de várias outras imagens ligadas ao sacrifício de Cristo. A presença dos pássaros também alude a um trânsito entre o céu e a terra, eles são os mensageiros de Deus. No campo simbólico, eles significam a espiritualidade de uma maneira geral. ${ }^{37}$ Notemos que é a pomba que representa o Espírito Santo tanto nas aparições miríficas quanto na iconografia

\footnotetext{
${ }^{34}$ Depoimento de Jahel Wanderley Cabral de 15/09/1891. In: Cópia autêntica..., op. cit., p. 22.

35 ELIADE, Mircea, idem, p. 81.

${ }^{36}$ GÉLIS, Jacques. O corpo, a Igreja e o sagrado. In: CORBIN, A., COURTINE, J. J. e VIGARELLO, G. História do corpo. Petrópolis, RJ: Vozes, 2008, p. 40.

${ }^{37}$ BETHENCOURT, Francisco. $O$ imaginário da magia: feiticeiras, adivinhos e curandeiros em Portugal no século XVI. São Paulo: Companhia das Letras, 2004, p. 153.
} 
REVISTA DE HISTÓRIA

SÃO PAULO, N $N^{\circ} 169$, p. 381-409,

JULHO / DEZEMBRO 2013
Edianne dos Santos Nobre

0 sagrado e a teatralização do mundo: espaços de salvação e purgaç̃ão nos relatos das beatas do padre Cícero

cristã. A imagem do pássaro também é recorrente na literatura religiosa para representar os anjos que, segundo são Paulo, são seres que "brilham como o Sol, têm o nome de Deus inscrito no peito e trazem a palma, símbolo da vitória contra o mal, e a cruz, símbolo maior para o cristão" ${ }^{38}$ Os anjos estavam presentes na criação e estarão presentes no juízo final, tendo em são Miguel seu grande líder.

Nos relatos das beatas, as visões de anjos são recorrentes e embora não haja nos relatos uma especificação mais detalhada de como eram esses anjos, de onde eles vinham ou se eram chamados por algum nome em especial, a relação das mulheres com eles também era de total intimidade, eles estavam sempre à disposição para auxiliá-las nos resgates das almas do Purgatório, bem como viviam a adorar o sangue precioso na igreja de Nossa Senhora das Dores:

Maria Leopoldina Ferreira da Soledade, natural da freguesia do Crato, ora residente na povoação do Juazeiro, idade de vinte e nove anos incompletos, solteira, testemunha jurada dos Santos Evangelhos [...] Respondeu que no dia 25 de março, tendo-lhe ordenado o confessor, depois de uma benção a ela dada em honra da S. S. Virgem, que ela testemunha adorasse a Nosso Senhor ali presente no Sacramento da Eucaristia, especialmente manifestado naquelas hóstias transformadas em sangue, logo depois de sua comunhão, teve ela de ver na Capela do S. S. Sacramento diversos anjos e dentre eles três que se nomearam por seus próprios nomes, sendo um - Testes fidelis - outro Reverentia - outro finalmente - Maravilha. ${ }^{39}$

Um dos anjos citados, Testes fidelis, que quer dizer testemunha fiel, seria uma referência a um anjo presente nas páginas dos Salmos bíblicos, conforme as pesquisas do antropólogo Salatiel Barbosa: "Sua descendência será perpétua, e seu trono é como o sol a minha frente, é como a lua, firmada para sempre, verdadeiro testemunho nas nuvens" (Sl 89 (88), p. 37-38). ${ }^{40} \mathrm{~A}$ menção de Testes fidelis adquire um sentido profético ao proclamar a presença constante da testemunha fiel do derramamento do sangue precioso de Cris-

\footnotetext{
${ }^{38}$ Apud CAMPOS, Adalgisa Arantes. São Miguel, as almas do Purgatório e as balanças: iconografia e veneração na época moderna. Memorandum, 7, 2004, p. 107.

${ }^{39}$ Auto de perguntas a Maria Leopoldina F. da Soledade de 17/09/1891. In: Cópia autêntica, op. cit., p. 23.

${ }^{40}$ Cf. BARBOSA, Francisco Salatiel de Alencar. O Joaseiro celeste: tempo e paisagem na devoção ao padre Cícero. São Paulo: Attar, 2007.
} 
REVISTA DE HISTÓRIA

SÃO PAULO, N 169 , p. 381-409,

JULHO / DEZEMBRO 2013
Edianne dos Santos Nobre

0 sagrado e a teatralização do mundo: espaços de salvação e purgação nos relatos das beatas do padre Cícero

to. Neste sentido, mencionar os nomes dos anjos talvez tenha o objetivo de dar credibilidade à narrativa. ${ }^{41}$

Por outro lado, também nos leva a pensar que estas mulheres se assumem como testemunhas de Cristo ao reivindicar a missão que mostra que Juazeiro é o lugar que Ele escolheu para sua segunda redenção. Sem exceção, todas essas "testemunhas" empregam em suas narrativas elementos da ortodoxia católica e aquelas mais instruídas trazem discussões mais profundas que visam dar legitimidade aos fenômenos nos quais elas são os instrumentos de Deus.

Para o jornalista José Marrocos ${ }^{42}$ a impressão que se tinha era que nada poderia destruir a "verdade" que ali se mostrava. Para os peregrinos e beatas, o sangue que brotava das hóstias e crucifixos era mesmo o sangue do próprio Jesus Cristo e, diante disso, a "proibição Diocesana desapareceu [...] e anulou-se mesmo diante desse poder que pisa por cima das duas forças invencíveis deste mundo: o poder da autoridade que manda e a submissão do súdito que obedece". ${ }^{43}$

Algumas "reivindicações" também são expressas nas visões, quando, por exemplo, em uma das visões de Maria de Araújo, "a S. S. Virgem recomendou que nesta Igreja do Juazeiro se cantasse, das seis para as sete horas da tarde o Ofício em honra de suas dores, prometendo muitas graças particulares que Deus tinha de dar a este lugar [...]".44 De fato, nas igrejas do Juazeiro, o Ofício da Imaculada Conceição de Maria é cantado até hoje, todos os dias ao cair da tarde. Esse ofício foi composto no século XV e é formado por sete hinos que louvam as virtudes de Maria e a tomam como a grande defensora das causas dos pecadores e intercessora fiel junto a seu filho.

\footnotetext{
${ }^{41}$ Infelizmente ainda não descobrimos referências diretas ao possível significado para os outros dois nomes: Reverentia e Maravilha. O primeiro, do latim (reverência), aparece na Bíblia mostrando que de uma "atitude de reverência, fluem com naturalidade os atos de obediência" (2 Co 7.1). Maravilha se refere possivelmente ao fato extraordinário realizado por intervenção divina, como em Mt 21.15.

${ }^{42}$ O jornalista e professor José Joaquim Telles de Marrocos (1842-1910) era primo e amigo íntimo do padre Cícero. Participou ativamente do movimento abolicionista cearense. Fundou junto com o padre José Ibiapina o primeiro jornal cratense de cunho religioso, chamado $A$ Voz da Religião no Cariri e o primeiro jornal de Juazeiro intitulado $O$ Rebate. José Marrocos atuava ainda em várias atividades religiosas e foi um arraigado defensor da veracidade dos fenômenos ocorridos com Maria de Araújo e com as outras beatas.

${ }^{43}$ Depoimento de José J. T. de Marrocos de 12/10/1891. In: Cópia autêntica..., op. cit., p. 68.

${ }^{44}$ Aditamento ao auto de perguntas feitas à Maria de Araújo de 11/09/1891. In: Cópia autêntica, op. cit., p. 14.
} 
REVISTA DE HISTÓRIA

SÃO PAULO, N $N^{\circ} 169$, p. 381-409,

JULHO / DEZEMBRO 2013
Edianne dos Santos Nobre

0 sagrado e a teatralização do mundo: espaç̦os de salvação e purgaç̃ão nos relatos das beatas do padre Cícero

No século XIX, a prática de se rezar o ofício respeitava os horários canônicos: Matinas (de madrugada), Prima (seis da manhã), Terça (nove da manhã), Sexta (meio-dia), Noa (três da tarde), Vésperas (seis da tarde) e Completas (cair da noite) e, na tradição popular, é sabido que, nas casas de família onde havia o costume de se rezar o ofício, todas as atividades domésticas paravam, porque "Nossa Senhora ficava de joelhos e de mãos postas, sem poder se levantar enquanto não viessem a completar o seu Ofício". ${ }^{45}$ Uma das estrofes do ofício é um belo poema de exaltação à virgindade de Maria e a sua função de intercessora entre os fiéis e Cristo: "Sede em meu favor/ Virgem soberana/ livrai-me do inimigo/ com vosso valor". Como nesse trecho do poema, em muitas visões, Maria assume o papel de intercessora: "[...] vi Nossa Senhora toda vestida de verde dizendo então: remetam ao Papa o processo que se há de fazer, o que respondendo eu que só seria remetido ao Papa se o Bispo mandasse, como me disse o padre, ela replicou: remetam para o Papa". ${ }^{46}$

A ênfase na ordem da Virgem Maria para que o processo fosse remetido para o papa representava provavelmente a esperança das mulheres - simbolizada também na cor verde do vestido de Maria - de que a Igreja católica apoiasse e se manifestasse a favor dos fenômenos que ocorriam em Juazeiro. Essa visão também se fundamentava na ideia de que as beatas tinham certeza de que o papa seria a favor dos milagres, pois ele mesmo não aprovara outros tantos $?^{47}$ Questionamos ainda em que medida não há uma influência externa dos sacerdotes na ênfase destas narrativas em achar que se o processo fosse remetido diretamente ao papa seria aprovado sem mais delongas? Não é coincidência que o padre Francisco Ferreira Antero, secretário da primeira comissão, tenha levado pessoalmente uma cópia a Roma sem autorização do diocesano. ${ }^{48} \mathrm{O}$ próprio Antero já afirmara também que

\footnotetext{
${ }^{45}$ VIANA apud MOTT, Luís. Rosa egipcíaca: uma santa africana no Brasil. Rio de Janeiro: Bertrand Brasil, 1993, p. 71.

${ }^{46}$ Aditamento ao depoimento de Jahel W. Cabral de 05/10/1891. In: Cópia autêntica, op. cit., p. 52. Grifo nosso.

${ }^{47}$ O mais famoso milagre eucarístico aconteceu em 1263 na cidade de Bolsena, quando o padre Pedro de Praga pôs em dúvida a presença de Cristo na Sagrada Eucaristia. Durante a missa, ao partir a hóstia, esta se transformou em carne viva, sangrando por todo o altar. Esse episódio inspirou o papa Urbano IV a criar a festa de Corpus Christi. Há outros menos famosos como o de santa Juliana Falconieri (século XIV) ou das beatas espanholas Madalena da Cruz e Maria da Visitação no século XVII. Cf. MOTT, op. cit., 1993, p. 142.

${ }^{48}$ O primeiro inquérito "acerca dos fatos extraordinários ocorridos nesta povoação do Juazeiro" foi instaurado pelo bispo diocesano dom Joaquim José Vieira em 19 de julho de 1891, depois de ouvir o padre Cícero Romão Batista falar sobre as circunstâncias de produção dos fenômenos e sobre a conduta da beata Maria de Araújo. A primeira comissão foi formada pelos padres
} 
REVISTA DE HISTÓRIA

SÃO PAULO, N 169 , p. 381-409,

JULHO / DEZEMBRO 2013
Edianne dos Santos Nobre

0 sagrado e a teatralização do mundo: espaços de salvação e purgação nos relatos das beatas do padre Cícero

se "Roma não autenticasse os milagres de Juazeiro, ela se defrontaria com a tarefa de invalidar 'milagres idênticos [que já tinham sido] aprovados pela Igreja' e nos quais os povos da França, de Portugal e da Itália vinham de longa data acreditando". ${ }^{49}$

Em outras visões, como nas da beata Jahel Cabral, o próprio Deus aparece em adoração aos panos "no Consistório da Capela do Juazeiro, trajando verde, em figura de um homem, ajoelhado diante da caixa de vidro, e logo depois teve um sonho no qual acordou quando se achava no Palácio Episcopal de Fortaleza". ${ }^{50}$ A mesma beata relata ainda que Deus (chamado por ela de Pai Eterno) surge nas visões com a intenção de ajudar as mulheres a convencer o bispo diocesano do caráter divino dos milagres:

Às dez horas do mesmo dia [04/09/1891], estava eu em oração, quando vi outra vez o Eterno Padre, dizendo-me então: Nos altos decretos de Deus foi permitido isso que o Bispo fez (E nisso mostrava-me uma carta); em seguida o Padre Eterno tomou-me pelas mãos dizendo: Vamos à casa do Bispo; quando ali chegamos, chamou ele pelo Bispo e ele [o bispo] não respondeu, o que se deu depois, digo, então eu indiquei que melhor seria subirmos, e o Eterno Padre disse em resposta: não, vamos ser os pequenos para depois sermos os grandes. Chamou pela segunda vez o Bispo, e vindo então algumas pessoas, da casa para saber do que queria, disse o Eterno Padre que queria falar com o Bispo mesmo, ao que ficando eles como que indiferentes, chamou terceira vez o Eterno Padre pelo Bispo, que não acudiu ao chamado, quando então disse o Eterno Padre - está vendo? Já é a terceira vez que o chamo, vamos embora, e nesse ínterim traçou uma cruz sobre a porta. ${ }^{51}$

A carta à qual a beata se refere e que é mostrada a ela pelo Pai Eterno, é possivelmente a decisão interlocutória do bispo (divulgada em 21 de julho de 1891) que proibia que se desse culto ao sangue que jorrava das hóstias. ${ }^{52}$ Mas a visão talvez deseje mostrar principalmente que o bispo diocesano não

Clicério da Costa Lobo (1839-1916) como delegado e o padre Francisco Ferreira Antero (18551929). Eles tinham como missão examinar as condições em que se dava o fenômeno e se ele era verdadeiro ou não. A versão em italiano se encontra no Archivo della Congregazione per la Dottrina della Fede no Vaticano em Roma. Recentemente, tivemos acesso a essa versão e aos bastidores do processo na Congregação. Analisamos esses documentos na tese de doutorado que desenvolvo no Programa de Pós-Graduação em História Social da UFRJ.

${ }^{49}$ Carta de padre Antero ao monsenhor Saluci de 05/08/1892, apud DELLA CAVA, op. cit., 1976, p. 69.

${ }^{50}$ Carta do padre Alexandrino de Alencar a d. Joaquim Vieira de 1895 (16/05/??) In: Anais, CRA 04,28, p. 262.

${ }^{51}$ Aditamento ao auto de perguntas da beata Jahel W. Cabral de 05.10.1891. In: Cópia autêntica, op. cit., p. 52.

52 Portaria do bispo d. Joaquim J. Vieira, de 21/07/1891 instaurando o processo In: Cópia autêntica, op. cit., p. 06. 
REVISTA DE HISTÓRIA

SÃO PAULO, N $N^{\circ} 169$, p. 381-409,

JULHO / DEZEMBRO 2013
Edianne dos Santos Nobre

0 sagrado e a teatralização do mundo: espaços de salvação e purgaç̃ão nos relatos das beatas do padre Cícero

estava conectado com Deus tanto quanto elas estavam. Ainda neste mesmo depoimento, a beata Jahel Cabral ressalta que o Pai Eterno teria chamado o bispo por três vezes. A simbologia do número três está presente em várias visões: três vezes Maria de Araújo teve de ir a Roma conversar com o papa; ${ }^{53}$ três anjos se nomearam perante Maria da Soledade e esta mesma beata tomou sobre si a incumbência de sufragar três almas; ${ }^{54}$ três vezes Anna Leopoldina teve de ir ao Céu; ${ }^{55}$ e no dia três de setembro de 1891, a Virgem Maria apareceu e "com ar de tristeza" disse a Maria de Araújo: Todos esses fatos aqui ocorridos são graças reservadas para os últimos tempos". ${ }^{56} \mathrm{O}$ número três representa justamente o Deus trinitário cristão (o Pai, o Filho e o Espírito Santo) simbolizando a perfeição divina, "exprimindo a síntese, a ordem espiritual em Deus, no cosmos e no homem".57

Essas visões ratificariam a proposição principal de que o espaço de Juazeiro era essencialmente um espaço de salvação porque ali há o derramamento do sangue de Cristo e este morreu na cruz para salvar a humanidade, redimindo-a de seus pecados. A imagem do derramamento também alude à sede. Na Bíblia, o amor de Cristo é comparado a uma fonte que jorra a água da vida para aqueles que têm sede: "Eu sou o Alfa e o Ômega, o Princípio e o Fim; e a quem tem sede eu darei gratuitamente da fonte de água viva" (Ap 21.6). Do mesmo modo, Juazeiro enquanto espaço escolhido por Cristo para sua segunda redenção, é o lugar de onde as graças são derramadas para o mundo inteiro:

[Jesus disse a Jahel Cabral] Eis aqui está (nesta caixa) o princípio das graças que hei de derramar sobre o mundo inteiro: quiseram muitos de secar o rio que jorra daquele princípio, mas por muito que tenham lutado para assim fazer, eu não consentirei; aí me era mostrado tendo Jesus aberto o coração, do qual jorrava um rio que regava toda a terra, como também me era representado o Padre Eterno e o Espírito Santo, de um e outro lado de Jesus. ${ }^{58}$

\footnotetext{
53 Aditamento ao auto de perguntas feitas à Maria de Araújo de 11/09/1891. In: Cópia autêntica, op. cit., p. 14.

${ }^{54}$ Auto de perguntas à Maria Leopoldina F. da Soledade de 17/09/1891. In: Cópia autêntica, op. cit., p. 23-25.

55 Auto de perguntas à Anna Leopoldina Aguiar Melo de 28/09/1891. In: Cópia autêntica, op. cit., p. 46.

${ }^{56}$ Aditamento ao auto de perguntas feitas à Maria de Araújo de 11/09/1891. In: Cópia autêntica, op. cit., p. 16.

57 BETHENCOURT, Francisco, op. cit., p. 136.

${ }^{58}$ Aditamento ao auto de perguntas da beata Jahel W. Cabral de 05/10/1891. In: Cópia autêntica, op. cit., p. 53.
} 
REVISTA DE HISTÓRIA

SÃO PAULO, N 169 , p. 381-409,

JULHO / DEZEMBRO 2013
Edianne dos Santos Nobre

0 sagrado e a teatralização do mundo: espaços de salvação e purgação nos relatos das beatas do padre Cícero

Novamente a Trindade se destaca na visão que fala sobre as graças reservadas àqueles que beberem da fonte da vida (do sangue) que é o coração de Jesus. Ela diz: "me era representado", aí temos não a percepção dos corpos da Trindade, mas uma "semelhança de corpos", sem o ser verdadeiramente. São imagens, representações, o que confirma a visão espiritual: "[...] É uma imago, uma 'imagem espiritual' e não 'corporal', que tem apenas a aparência de um corpo. [...] Todas essas imagens são percebidas não pelos olhos do corpo, mas pelos 'olhos da alma' [...]".59

Os diversos personagens que compõem as cenas representadas nas visões dão legitimidade aos relatos das beatas (ainda que considerarmos que os relatos passam pelo filtro dos comissários do bispo), isto é, a afirmação de Juazeiro como espaço sagrado e da igreja de Nossa Senhora das Dores como lugar de salvação não é feita somente pelas mulheres, mas também por anjos e santos, pela Trindade, pela Virgem Maria e até mesmo pelo papa (que fora das visões apoiou a Diocese e condenou os milagres).

\section{Purgatório na Terra: o sufrágio de dois bispos e um cardeal}

O que mais nos chamou a atenção nos relatos que falam do Purgatório foram os episódios ocorridos com a beata Maria da Soledade. Esta beata era "natural da freguesia do Crato, ora residente na povoação do Juazeiro, idade de vinte nove anos incompletos, solteira" e contou para a comissão episcopal como a igreja do Juazeiro se tornou um Purgatório temporário e ela - auxiliada pelo padre Cícero -, a responsável pelo sufrágio de certas almas que foram para lá, a fim de purgar seus pecados.

A "transposição" momentânea do Purgatório para o espaço de Juazeiro ou mesmo o fato de que uma das principais missões das beatas consistisse em "tirar almas do Purgatório" - aliás, essa era uma missão comum aos místicos - aponta, ainda, para a importância dos sufrágios em uma sociedade que acreditava nos destinos individuais e na nova redenção de Cristo. $\mathrm{O}$ poder de trânsito entre os espaços do além e da terra ratificadas pelo próprio Deus faz alusão ainda à própria descida do Cristo aos infernos a fim de libertar as almas (Mt 12,40; At 2,31).

Na geografia dos espaços do além, o sistema de orientação espaço-simbólico da Igreja cristã era fundamentado na relação alto-baixo, isto é, existia

\footnotetext{
${ }^{59}$ SCHMITT, Jean-Claude. Os vivos e os mortos na sociedade medieval. São Paulo: Companhia das Letras, 1999, p. 41-42. Grifos no original.
} 
REVISTA DE HISTÓRIA

SÃO PAULO, N $N^{\circ} 169$, p. 381-409,

JULHO / DEZEMBRO 2013
Edianne dos Santos Nobre

0 sagrado e a teatralização do mundo: espaços de salvação e purgação nos relatos das beatas do padre Cícero

um lugar de recompensa (alto/céu) e um lugar de punição (baixo/inferno). No final do século XII, com o surgimento da palavra purgatorium (lugar de purgação; purgatorius, purgatoria, que expurga), esses espaços começam a tomar forma mais consistente o que se manifesta na divisão entre os lugares de purgação e os lugares de punição. O Purgatório seria, portanto, um intervalo que tem como principal função estabelecer as ligações entre o mundo dos vivos e o mundo dos mortos.

À noção de Purgatório se liga ainda a ideia de responsabilidade pessoal, pois para lá só vão aquelas almas que caíram em pecados veniais (pecados perdoáveis). É por esse motivo que o Purgatório se apresenta, acima de tudo, como um lugar de esperança, onde o cristão poderia experimentar mais avidamente a misericórdia de Deus. É justamente o fator esperança que diferencia Inferno e Purgatório de maneira mais inteligível. No inferno, a alma já está condenada e não existe a possibilidade da fuga ou da redenção: "Deixai, ó vós que entrais, toda a esperança”, é a frase impressa nos umbrais do Inferno visitado por Dante. ${ }^{60}$

A existência do Purgatório está, pois, ligada à própria existência/conduta do cristão no mundo e subentende uma ideia de continuidade entre o espaço terreno e o além da purgação. Consideramos que esse espaço do além, o Purgatório, estaria separado do plano terreno por uma linha bastante tênue, daí a possibilidade das viagens espirituais ao Purgatório, bem como das visitas espectrais aos espaços terrenos.

A prática da comunicação com os mortos pertencia a uma visão mágica do mundo que foi sendo incorporada pela Igreja católica. No século XVI, muitas orações e práticas mágicas associavam as almas do Purgatório às práticas de adivinhação. A devoção dos finados fazia parte de um universo que considerava que as almas eram onipresentes e tinham a capacidade de dizer onde se achavam as coisas ou pessoas perdidas, bem como de adivinhar o futuro. No entanto, essas práticas se utilizavam com frequência de elementos da ortodoxia cristã, demonstrando mais uma vez a tênue linha que separa os ritos considerados "supersticiosos" ou "populares", dos ritos canônicos oficiais. ${ }^{61}$

O Purgatório aparece com uma prerrogativa importante: seu funcionamento dependia integralmente da intervenção dos vivos e das relações de solidariedade que se estabeleceram em vida e que continuam na morte, pois

\footnotetext{
${ }^{60}$ ALIGHIERI, Dante. A divina comédia: Inferno, Purgatório e Paraíso. $2^{\mathrm{a}}$ edição. Belo Horizonte: Itatiaia; São Paulo: Edusp, 1979, p. 110.

${ }^{61}$ BETHENCOURT, Francisco, op. cit., p. 69.
} 
REVISTA DE HISTÓRIA

SÃO PAULO, N 169 , p. 381-409,

JULHO / DEZEMBRO 2013
Edianne dos Santos Nobre

0 sagrado e a teatralização do mundo: espaços de salvação e purgação nos relatos das beatas do padre Cícero

as almas precisam de missas e orações para alívio dos seus tormentos (Idem, 148). O sufrágio pelos mortos irá então se constituir como prática obrigatória do cristão católico.

No século XVI, o Concílio de Trento, em sua sessão XXV, já considerava que "as almas presas nele [Purgatório] recebem com alívio os sufrágios dos fiéis" e mandava que os bispos fizessem com que os sufrágios, a saber, "os sacrifícios das missas, das orações, as esmolas e outras obras de piedade, que se acostumam a fazer por outros fiéis defuntos, se executem piedosa e devotamente segundo o estabelecido pela Igreja". ${ }^{22}$ Após 1650, os livros de oração se popularizaram na Europa e, neste contexto, a pastoral em favor das almas do Purgatório ganha importância e rápida divulgação, chegando ao Brasil através das missões de jesuítas e capuchinhos. Em Portugal, a devoção às almas do Purgatório, também ganha dimensão a partir dos Setecentos e são criadas várias confrarias das almas com a função de promover cerimônias religiosas ligadas ao sufrágio das almas. ${ }^{63}$

O padre jesuíta Manoel do Couto (1819-1897) ${ }^{64}$ assimila o Purgatório ao Inferno quando descreve o último como "uma caverna profundíssima cheia de escuridão, de tristeza e horror; é uma caverna cheia de lavaredas de fogo e de nuvens de espesso fumo", 65 daí que o Purgatório é definido como um lugar onde os tormentos são "tais quais os do inferno, só não são eternos".66 Segundo Jacques Le Goff, as tentativas de espacialização do Purgatório na terra, ou pelo menos seus acessos, associavam este aos vulcões que, supunham, eram entradas que levavam ao centro da terra. ${ }^{67}$

\footnotetext{
62 "[...] las almas detenidas en él reciben alivio con los sufragios de los fieles [...] los sacrificios de las misas, las oraciones, las limosnas y otras obras de piedad, que se acostumbran hacer por otros fieles difuntos, se ejecuten piadosa y devotamente según lo establecido por la Iglesia" In:Documentos do Concílio de Trento, sessão XXV, cap. I "Decreto sobre el Purgatorio". Tradução nossa. Disponível em Biblioteca Electrónica Cristiana - http://multimedios.org/docs/d000436/.

${ }^{63}$ OLIVEIRA, Maria Gabriela Gomes de. Uma "irmandade" volante do século XVIII, o folheto "Lágrimas da alma". Revista da Faculdade de Letras, Línguas e Literatura, série II, vol. 9. Lisboa: Instituto de Cultura Portuguesa, 1992, p. 349-353.

${ }^{64}$ Autor do livro de prédicas "Missão abreviada para despertar os descuidados, converter os pecadores e sustentar os frutos das missões" (1868). Esse livro era bastante utilizado pelos padres da região do Cariri no final do século XIX e até hoje está presente e é amplamente divulgado pela principal ordem de penitentes do Cariri cearense, os Aves de Jesus.

${ }^{65}$ COUTO, padre Manuel Gonçalves. Missão abreviada: para despertar os descuidados, converter os pecadores e sustentar os frutos das missões. 12a edição. Porto: Sebastião José Pereira Editor, 1868, p. 78.

${ }^{66}$ COUTO, padre Manuel Gonçalves, op. cit., p. 528.

${ }^{67}$ LE GOFF, Jacques. La naissaince du Purgatoire. Paris: Gallimard, 1981, p. 20.
} 
REVISTA DE HISTÓRIA

SÃO PAULO, N $N^{\circ} 169$, p. 381-409,

JULHO / DEZEMBRO 2013
Edianne dos Santos Nobre

0 sagrado e a teatralização do mundo: espaç̦os de salvação e purgaç̃ão nos relatos das beatas do padre Cícero

A crença de que as orações dos vivos são eficazes na redenção de certos mortos construiu uma visão de mundo baseada nas expectativas com relação à vida após a morte. Está em jogo o destino das almas, tanto o destino individual - no qual prevalece a certeza de um julgamento imediato após a morte que o leva ao Purgatório ou direto ao Inferno, pois, somente a alguns pouco escolhidos compete ir direto para o Céu - quanto um destino coletivo, onde se afirma a crença no juízo final (Apocalipse) e na segunda redenção de Cristo. Assim é que Maria de Araújo "aprende" do próprio Cristo uma oração que envolve as almas do Purgatório:

Lembra-se e pode comunicar alguma das orações que aprendeu da boca de Nosso Senhor? Respondeu [Maria de Araújo] que sim e disse ser uma delas: “Louvada seja a morte e paixão de Jesus Cristo e as dores da Imaculada sempre Virgem Maria - e mandava dizer ainda - Meu pai abençoe a mim e as almas do Purgatório e tudo que Jesus, Maria e José queiram abençoar; que sejam todos abençoados e salvos pelo Sagrado Coração de Jesus e seu preciosíssimo sangue", com promessa de indulgência toda vez que fossem recitadas essas preces. ${ }^{68}$

A crença nas almas do Purgatório e que suas orações a favor delas resultariam em indulgências para a própria alma está marcada na própria cultura religiosa herdada por essas mulheres. Há, pois, uma permanência desses elementos ligados ao catolicismo penitencial na vivência e nas práticas religiosas das beatas do Juazeiro. O trânsito entre os espaços do além aparece quase que naturalizado nas narrativas e, de fato, essas mulheres mantêm uma relação muito peculiar com o sobrenatural.

Um exemplo que ilustra essa relação é o episódio dos sufrágios de dois bispos e um cardeal, conforme podemos acompanhar na narrativa de Maria da Soledade. Ao ser inquirida, Maria da Soledade contou à Comissão Episcopal que com ela se deu o seguinte:

No dia 23 de dezembro de 1890, por ocasião de confessar-me, foi-me imposta como penitência sacramental dar-me toda a Deus para em honra do preciosíssimo sangue de Jesus, das dores de sua Mãe S. S. e maior glória da Trindade S. S., tomar sobre mim as penas de três almas que fossem de papas e assim libertá-las do Purgatório. Sucedeu, porém, que Nosso Senhor não aceitou essa oblação em relação aos papas e substituiu aplicando-a as almas de um Cardeal e dois bispos. No mesmo dia apareceram estas três almas, na ocasião da missa, e perguntando-lhes o padre Cícero quem eram, o que fez em nome e em obediência a Deus, responderam uma que era um Cardeal, e as outras

\footnotetext{
${ }^{68}$ Auto de perguntas a Maria de Araújo de 09/09/1891. In: Cópia autêntica, op. cit., p. 09.
} 
REVISTA DE HISTÓRIA

SÃO PAULO, N ${ }^{\circ} 169$, p. 381-409,

JULHO / DEZEMBRO 2013
Edianne dos Santos Nobre

0 sagrado e a teatralização do mundo: espaços de salvação e purgação nos relatos das beatas do padre Cícero

que eram - Episcopus Joachinus et Episcopus Petrus - o primeiro que foi antecessor do Arcebispo da Bahia D. Luiz, o segundo, que foi bispo do Rio de Janeiro. Desde esse dia até o dia seis de janeiro do ano seguinte, estas três almas vinham todos os dias a assistir a missa, colocando-se os dois bispos de um e outro lado e o Cardeal no meio; todos possuídos do maior acatamento [...].69

Neste caso, a beata não vai ao Purgatório ajudar as almas, mas as almas que lá estão cumprindo penitência vêm à igreja onde o sangue de Cristo teria sido derramado para serem perdoadas de seus pecados, sendo que o cardeal foi o único que não se identificou de imediato. Note-se que a beata fala das "almas" dos sacerdotes e não dos seus "fantasmas", o que é interessante, pois denota a influência das prédicas penitenciais que fala das "almas do purgatório". Embora não exista uma diferenciação segura entre fantasma e alma (ambos são imateriais), o termo alma (do latim, anima) sugere uma interpretação mais voltada para o sagrado, enquanto fantasma sugere um tom mais profano. ${ }^{70}$ Neste relato, está presente também a ideia de um fogo purgatório, um fogo que "queima sem consumir", e que é amenizado paulatinamente com as penitências feitas em sufrágio daqueles que lá padecem.

A beata permanece firme em sua missão de sufragar as almas que ali estavam se penitenciando e narra com detalhes como se comportavam as almas durante o tempo em que permaneceram lá na igreja do Juazeiro, estas sempre em posição de adoração ao sangue precioso (os panos manchados de sangue) que estava na caixa de vidro no sacrário que guardava a imagem do Sagrado Coração de Jesus:

No dia 26 de Dezembro do ano passado, sucedeu que, ao tocar - Sanctus - o Cardeal, inflamado com as chamas de amor que, saindo do Sacrário envolviam o Sacerdote oficiante e se transmitiam ao mesmo Cardeal, sentiu-se incitado a subir ao altar, onde prostrado com a face em terra, em adoração ao sangue de Jesus que então caía sobre ele, como chuva, exclamou: "- oh, amor!" conservando-se nessa posição até o fim da missa. No dia 28 do mesmo mês e ano já declarados continuando-se a sufragar as ditas almas; por ocasião da consagração na missa, o Cardeal elevando as mãos e os olhos, e seu rosto desfazendo-se então em chamas, exclamou: “Oh! levita do Santuário, tenro arbusto sacerdotal, vaso de eleição, chamado a serdes sentinela em Israel, vós doce

\footnotetext{
${ }^{69}$ Auto de perguntas à Maria Leopoldina F. da Soledade de 17/09/1891. In: Cópia autêntica, op. cit., p. 23-25. Supomos que aqui, Maria da Soledade, refere-se aos bispos dom Joaquim Gonçalves de Azevedo, ex-arcebispo da Bahia que morreu em 1879, e ao ex-bispo do Rio de Janeiro, Pedro Maria de Lacerda que morreu em 1890.

${ }^{70}$ Idem, ibidem.
} 
REVISTA DE HISTÓRIA

SÃO PAULO, N $N^{\circ} 169$, p. 381-409,

JULHO / DEZEMBRO 2013
Edianne dos Santos Nobre

0 sagrado e a teatralização do mundo: espaç̦os de salvação e purgaç̃ão nos relatos das beatas do padre Cícero

esperança de nossos gozos e resplendores eternos, chegai-vos a este vulcão de amor (e isto dizendo, apontava para um retábulo do Sagrado Coração de Jesus e o tabernáculo e a caixa de vidro contendo as partículas transformadas em sangue) atirai-vos às ardentes chamas, acendei-vos em seu abrasado ardor para serdes luz e calor no meio das nossas trevas"; terminando com dizer duas vezes "- luce mea, ardens, ardens".71

O fogo manifestado na igreja do Juazeiro é outro indício que demonstra que aquele lugar temporariamente servia como um Purgatório. A presença dele na narrativa de Maria da Soledade - "desfazendo-se em chamas", "vulcão de amor", "ardentes chamas", "abrasado ardor" -, está diretamente relacionada ao ato de purgar. Ora, não existe purgação sem o fogo purgatório, pois, "o fogo porá à prova a obra de cada um" (1Co 3.13). Conforme Le Goff, o fogo purgatório tem duas características principais. A primeira é que ele é um fogo "à travers lequel on passe", pelo qual se passa, isto é, o fogo purgatório se constitui por excelência em um ordálio, uma prova. São Paulo diz: “Ele será salvo, todavia como pelo fogo" (1 Co 3.15).

A segunda característica é que o Purgatório é formado a partir de um par, o fogo e a água, que nas representações medievais indica que o Purgatório possui lugares ígneos e lugares úmidos e a principal provação das almas seria a passagem alternada pelo fogo e pela água gelada. Nos depoimentos de Maria da Soledade, não temos a imagem da água. Somente o fogo aparece, em várias formas, inclusive na imagem de um "vulcão de amor" fazendo uma analogia entre o calor do fogo e o calor do amor. Não obstante essas variações, o fogo purgatório tem uma função principal onde quer que seja representado, que é o da salvação pela purificação e é neste sentido que ele aparecerá nas narrativas de Maria da Soledade.

O sufrágio do cardeal é o ponto alto da narrativa. Solicitado a dizer seu nome, ele responde: "Ego sum Cardinalis Pecci" ("Eu sou o cardeal Pecci), repetindo três vezes esta frase. É provável que Maria da Soledade estivesse se referindo a Giuseppe Pecci (1807-1890), ex-prefeito da Congregação para Estudos do Vaticano, que havia falecido em 8 de fevereiro de 1890. Este cardeal era também irmão de Gioacchino Pecci, o papa Leão XIII. ${ }^{72}$

Segundo o padre Alexandrino de Alencar, delegado da Segunda Comissão Episcopal, a visão foi "fabricada" no intuito de "dispor bem o Santo

\footnotetext{
${ }^{71}$ Idem.

${ }^{72}$ Consultamos o site do Vaticano que contém a lista dos papas e cardeais da Igreja católica, ordenada por século. Disponível em http://www.vatican.va, além da Biblioteca Electrónica Cristiana, BEC.
} 
REVISTA DE HISTÓRIA

SÃO PAULO, N 169 , p. 381-409,

JULHO / DEZEMBRO 2013
Edianne dos Santos Nobre

0 sagrado e a teatralização do mundo: espaços de salvação e purgação nos relatos das beatas do padre Cícero

Padre em favor de Juazeiro", pois corria na região a notícia de que "Leão XIII teve notícia disto, chorou e ficou bem disposto em favor da causa".73 Transcrevemos o relato, embora ele seja um pouco longo, pois nele temos o que seria a própria fala do cardeal dando seu testemunho e descrevendo seus sentimentos diante da iminência de ir para o Céu:

\begin{abstract}
Finalmente, no dia seguinte, 6 do mês e ano já declarado, assistindo missa aquelas três almas, levadas todas e possuídas do maior acatamento, depois da benção do $\mathrm{S}$. S. Sacramento a que assistiram o Cardeal, como que fora de si, somente possuído de Deus, erguendo as mãos exclamou: "Oh! Caríssimo e dedicado irmão, que amor, que ternura e que reconhecimento não devo eu ter para convosco, quando considero que fostes o instrumento pelo qual se quebraram cadeias que me detinham nesse cárcere, depois de minha morte; por meio e intermédio de vós é tempo hoje de eu consumar todos os meus trabalhos, subindo da terra ao Céu para habitar, reinar e glorificar aquele que é o princípio e o fim de todas as cousas; vou por tanto entrar no gozo do meu Senhor; e assim, como tomastes parte no meu doloroso e delatado exílio, tomai hoje parte nesta enchente de alegria de que a minha alma está penetrada, e que é o fim de tantas dores, lágrimas e gemidos. Eu me vou para o seio de Deus... para acabar de consumar as minhas vitórias sobre o mundo, o inferno e o pecado, pela minha entrada gloriosa e triunfante em seu reino; [...]" - e isto dizendo, voou para o céu, acompanhado de seu Anjo Custódio e de todos os santos que foram seus protetores e advogados neste mundo. ${ }^{74}$
\end{abstract}

Um elemento a se considerar é que, destarte a tentativa de localização do Purgatório feita por alguns santos e teólogos da Igreja católica, predomina em relação a ele um sentimento de libertação espacial, onde o Purgatório antes de ser um lugar, é um estado, uma situação: "pour la théologie catholique moderne le Purgatoire n'est pas un lieu mais un état [...] Le Purgatoire sera un habitacle ou un ensemble d'habitacles, un lieu de renfermement mais aussi de l'Enfer au Purgatoire, du Purgatoire au Paradis, le territoire s'agrandit, l'espace se dilate". ${ }^{75}$ Por isso, justificase que o Purgatório possa estar em qualquer lugar, é um espaço que cresce, um espaço que se dilata. Embora estivesse na igreja do Juazeiro, o cardeal estava constantemente cercado pelo fogo, pelas chamas ardentes, preso nas

\footnotetext{
${ }^{73}$ Carta do padre Alexandrino de Alencar a d. Joaquim Vieira de 28/06/1892. CRA 04,07, Anais, op. cit., p. 227.

${ }^{74}$ Auto de perguntas à Maria L. F. da Soledade de 17/09/1891. In: Cópia autêntica, op. cit., p. 24-25. Grifo nosso.

${ }^{75}$ LE GOFF, Jacques, op. cit., p. 25;52. Tradução nossa: “[...] para a teologia católica moderna o Purgatório não é um lugar mas um estado [...] O Purgatório seria um habitáculo ou um conjunto de habitáculos, um lugar de encarceramento, mas também do Inferno ao Purgatório, do Purgatório ao Paraíso, o território se alarga, o espaço se dilata".
} 
REVISTA DE HISTÓRIA

SÃO PAULO, N $N^{\circ} 169$, p. 381-409,

JULHO / DEZEMBRO 2013
Edianne dos Santos Nobre

0 sagrado e a teatralização do mundo: espaços de salvação e purgação nos relatos das beatas do padre Cícero

"cadeias de um cárcere" desde a sua morte, sentindo dores que se manifestavam nas lágrimas e nos gemidos.

O seu sufrágio representa então uma vitória "sobre o mundo, o inferno e o pecado". A descrição de sua ida para o Céu também denota uma obediência ao sistema espacial do além, ele voa para o Céu, ele sobe. O sistema alto/baixo prevalecerá nas representações mais tradicionais desses espaços. Lembremos, por exemplo, a narrativa de Dante que mostra uma trajetória desde o Inferno até o Paraíso, passando pelo intermediário Purgatório. A presença do anjo da guarda do cardeal, bem como de seus santos protetores (não nomeados) dá à imagem uma aura celestial. Continuando sua narração, Maria da Soledade conta que, em 18 de janeiro e 2 de fevereiro, respectivamente os bispos dom Joaquim e dom Pedro conseguiram o sufrágio de suas almas sendo suas "subidas triunfantes" acompanhadas de "exclamações cheias de amor" por parte dela, do sacerdote e dos anjos e santos.

Para a Diocese, essas visões não passavam de artimanhas e invenções das beatas que pretendiam com isso destruir a autoridade diocesana, uma vez que esta não dava crédito aos "pretensos milagres" ocorridos em Juazeiro. Entretanto, o depoimento de Maria da Soledade nos permite apreender um pouco da forma como as relações entre o mundo terreno e o mundo espiritual são concebidas por essas mulheres. Utilizando-se, ainda, do recurso de ligar seus atos à própria instituição eclesiástica representada na figura do confessor, as mulheres erigem para si um lugar de fala que exprime suas crenças e, ao mesmo tempo, ratifica certos dogmas da Igreja.

As almas de sacerdotes, o sacrifício da missa e as orações de sufrágio são, portanto, elementos presentes no conteúdo de uma existência que constrói um sentido baseado no seu valor de sagrado. Estas práticas sugerem também a intimidade da relação dessas mulheres com o sagrado, intimidade essa que não é partilhada pelos próprios eclesiásticos.

As representações espaciais presentes nos depoimentos são baseadas na própria experimentação de um espaço místico que se utiliza de elementos de um sistema simbólico vivenciado nas relações com o sobrenatural, com o mistério. Isso remete à identificação de um espaço de experiência que permite pensar Juazeiro como um lugar sagrado que forja um horizonte de expectativa da redenção dos pecados.

É o espaço escolhido por Deus que absorve essas características de santidade e que, nas narrativas, ganha status de sacralidade. Também podemos supor, a partir da narrativa de Maria da Soledade, que, ao transportar as almas dos bispos e do cardeal até a capela do Juazeiro, quer-se mostrar que se lá é um espaço em que até os sacerdotes vêm purgar após a morte, não 
REVISTA DE HISTÓRIA

SÃO PAULO, N 169 , p. 381-409,

JULHO / DEZEMBRO 2013
Edianne dos Santos Nobre

0 sagrado e a teatralização do mundo: espaços de salvação e purgação nos relatos das beatas do padre Cícero

deveria haver por parte da Igreja uma recusa ou mesmo uma descrença da sacralidade que aquele espaço condensa.

Infelizmente, pouco ficou registrado sobre a vida desta beata. Sabemos que, em outubro de 1892, depois que a segunda comissão fez as experiências com Maria de Araújo e atuava no sentido de conseguir as retratações das outras beatas, ela foi a Barbalha (cidade que faz divisa com Juazeiro e Crato) onde apresentou ao padre Joaquim Sother de Alencar (1858-1914) uma hóstia que havia sangrado em sua boca. ${ }^{76}$ Logo depois, ela foi a Jardim (outra cidade do Cariri) onde "uma hóstia que ela não pode consumir foi posta no altar" pelo padre Vicente Sother Alencar (1866-1946). Em janeiro de 1893, as pessoas que assistiram aos fenômenos com Maria da Soledade registraram no cartório de Jardim um documento atestando o "milagre".77

Em 20 de setembro de 1894, ela foi intimada a depor pelo padre Alexandrino e, embora não tenhamos conhecimento de qual foi sua resposta, sabemos que, em 20 de outubro, ela foi proibida de receber qualquer sacramento juntamente com as beatas Maria das Dores, Joanna Tertulina da Conceição e Antonia Maria da Conceição. Do que sabemos da trajetória desta beata nos diz que sua insistência em afirmar a veracidade dos fenômenos levou-a também a perder o hábito religioso. ${ }^{78}$

No entanto, ela começou a evitar o encontro com o padre Alexandrino. Em bilhete de 2 de novembro de 1894, ela escreve ao padre Alexandrino dizendo que recebeu as ordens do mesmo de ir encontrar-se com ele "e não sei como possam cumprir as ordens determinadas em virtude dos muitos ataques espasmódicos que constantemente sofro como V. Revma. sabe e assim não posso afirmar minha ida, só sim, se me for possível".79 Em data desconhecida de 1895, ela é finalmente intimada a tirar o manto de beata: "Disse-lhes com toda clareza que do hábito religioso não usariam nunca mais". ${ }^{80}$ Assim, em 1895, Maria da Soledade achava-se oficialmente privada do uso do manto de beata e privada dos sacramentos, isto é, não poderia mais confessar e comungar do corpo de Cristo, portanto, não seria absolvida de seus pecados

\footnotetext{
${ }^{76}$ Carta do padre Alexandrino de Alencar a d. Joaquim Vieira de 28/02/1893. CRA 14,128, Anais, op. cit., p. 235.

77 Segundo Della Cava esses fenômenos foram divulgados no jornal A Província do Recife, PE em 20 de janeiro de 1893. Cf. DELLA CAVA, 1976, op. cit., p. 98, nota 23.

${ }^{78}$ Carta do padre Alexandrino Alencar a d. Joaquim Vieira, sem data, provavelmente do final de 1893. CPR/CRA 04,28.

79 Bilhete de Maria Leopoldina F. da Soledade de 02.11.1894. CPR/CRA 07,33.

${ }^{80}$ Carta do padre Alexandrino Alencar a d. Joaquim Vieira de 1895 (16/05/ ?). CRA: 04,28. Anais, p. 262.
} 
REVISTA DE HISTÓRIA

SÃO PAULO, N $N^{\circ} 169$, p. 381-409,

JULHO / DEZEMBRO 2013
Edianne dos Santos Nobre

0 sagrado e a teatralização do mundo: espaços de salvação e purgação nos relatos das beatas do padre Cícero

e, se viesse a morrer, não receberia a extrema-unção. ${ }^{81}$ Já a beata Maria de Araújo, condenada como embusteira pela Congregação para a Doutrina da Fé, de acordo com o Decreto de 4 de abril de $1894,{ }^{82}$ jamais se retratou ou negou os fenômenos que ocorreram entre 1889 e 1891. Ela se recolheu em uma casa, pertencente hoje às irmãs salesianas, e ali faleceu em janeiro de 1914. Sobre o destino das outras mulheres pouco sabemos, pois elas simplesmente somem da documentação após 1894; algumas delas aparecem uma ou outra vez na correspondência dirigida ao bispo dom Joaquim José Vieira.

A partir das questões discutidas aqui inferimos que, com base nos depoimentos das mulheres e dos padres que se posicionavam a favor dos milagres, o espaço em Juazeiro foi construído a partir dessa dupla demanda. Em primeiro lugar, com uma função de lugar de salvação, a partir das imagens construídas nos relatos das beatas que pretendiam chamar atenção para um novo culto, o do sangue precioso. Em segundo lugar, Juazeiro como um lugar de purgação dos pecados, semelhante ao Purgatório cristão. Neste último, o espaço se transforma, assumindo uma função de lugar purgatório, sendo marcado pela visita de almas ao Juazeiro em busca do sufrágio que é, por sua vez, conseguido através de certas penitências. Daí que esse espaço pode tanto ser o teatro onde é encenada a Paixão de Cristo, como pode servir de palco para a expiação das almas do purgatório. Neste sentido, quisemos mostrar como os diversos personagens dessa trama - a Diocese, os sacerdotes, os crentes no sangue precioso e principalmente as beatas - expressaram, em suas relações, a construção do espaço de Juazeiro.

Recebido: 18/06/2012 - Aprovado: 23/04/2013.

\footnotetext{
${ }^{81}$ Carta do padre Alexandrino Alencar a d. Joaquim Vieira de 20/10/1894. CRA: 04,26. Anais, p. 250-251.

${ }^{82}$ Decreta Universa, anno 1894 edita. Feriae IV Aprilis. Archivo della Congregazione per la Dottrina della Fede, Cità del Vaticano, Roma.
} 
